\title{
The Vision of Paradise for People in Difficulties: The Solution Shown by a Russian Architect
}

\author{
Michel-Masafumi Ikeda ${ }^{1}$
}

${ }^{1}$ Cornerstone

\begin{abstract}
The Eastern Orthodox is a minority in Japan. However, it played an important role in the modernization of architecture. This paper aims to review their early architectural activities, and further to uncover the influences they received from the Russian architect whose name was Mikhail Aref'evich Shchurupov.

The architecture of Orthodox Church in Japan began from the conversion of existing private houses to chapels. The eclectic chapels followed them. The Resurrection Cathedral in Tokyo, designed by Shchurupov, made an epoch in the history of architecture in Japan. Needless to say, its greatest impact was on the Orthodox Church itself. The believers opened their eyes to the authentic western architecture. The churches at each stage can be seen in Kashiwa, Ishinomaki, and Odate.

Shchurupov left a number of churches in Russia. Three of them, still existing around St. Petersburg, show the trajectory on which he explored the lightweight and inexpensive structure to build churches for the economically challenged parishes facing difficult geological conditions. At first, he showed a structural rationalism. Then, he tried to build a dome with wood. At last, he reached to the steel structure.

At the Orthodox Churches, the division of interior space is emphasized and visualized. Each space symbolically plays various roles during the liturgy, and gives the believers the pseudo experience of the visit of heaven, which enables them to pass the faith across generations. The fact that the early believers in Japan projected the vision of paradise to the nave of their chapel means that they had reached the essence of church architecture.

Shchurupov's architectural features were suitable to the Orthodox Church in Japan in various difficulties as a religious minority. His idea and concept reflected in the Resurrection Cathedral enabled the believers in Japan to maintain their worship facilities for a long time.
\end{abstract}

(C) 2020 The Authors. Published by IEREK press. This is an open access article under the CC BY license (https://creativecommons.org/licenses/by/4.0/).

\section{Keywords}

Eastern Orthodox ; Japan ; Russia ; architect ; structure ; interior ; rationalism ;

\section{Introduction}

Christianity is a religious minority in Japan. Approximately one million Christians, constituting less than one percent of the entire population live peacefully in the archipelago. The Eastern Orthodox is further a minority in the Japanese Christian society. The number of believers is approximately ten thousand (Christian Yearbook, 2017). This minor group, however, played an important role in the modernization of Japanese architecture in its early era. This paper aims to review the early architectural activities of the Eastern Orthodox in Japan, with focus on the quality of space as religious facilities, and further to uncover the influence that a Russian architect had on these activities. 
The history of the Orthodox Church in Japan (OCJ) is one of the main themes of Russo-Japanese exchange history. Nakamura, K. Nakamura, Y., Yasui, and Naganawa (2007) have long driven its main parts, and have published many articles including the first full Japanese translation of the diary of monk Nicholas. Suzuki, K. (1983) conducted an exhaustive survey on the architecture of OCJ, however only refered to materials available in Japan. Upon the restoration the Resurrection Cathedral in Tokyo, Suzuki, S. et al. (1998) published a report that covered a lot of information about the building. Kawahigashi and Fujiki (2008) also have put this cathedral within research range as a part of their study on architect Josiah Conder, and surveyed on the buildings attached. Izumida (2010, 2013, \& 2018) and Ishikawa (2018) published literatures on OCJ's architecture in the twenteenth century, using Russian sources for the first time. However, no comparative study with Russia on OCJ's architecture in the nineteenth century has been conducted.

In Russia, Yakovlev (2001) published a detailed biography of architect Mikhail Shchurupov, who designed the Resurrection Cathedral in Tokyo. Savel'ev (2005) and Kishikinova (2007) published literature about Byzantine Revival movement in the late nineteenth century. The author referred those materials above, visited the Shchurupov's works remaining or restored in Russia, reviewed them, and compared them to OCJ's architecture in the nineteenth century.

\section{The Early Activities of the Eastern Orthodox in Japan}

After the long ban of Christianity by the shogunate, a number of denominations began to spread the Gospel again in Japan in the latter half of the nineteenth century. The Orthodox Church from Russia was not an exception. The first Orthodox chapel in Japan was attached to the Russian Consulate in Hakodate in 1860. Then, Ivan Dimitrovich Kasatkin, well-known by his monk's name Nicholas (1836-1912), came to Japan in 1861, and began to propagate Christianity to the Japanese people.

After the civil war from 1868 to 1869 , the Orthodox was rapidly accepted in the Tohoku region, the north-eastern part of mainland Japan, by the former samurai class and the farmers in their territories, who had supported the old shogunate regime in the civil war. The Orthodox Church succeeded in providing a vision of salvation and resurrection to the people facing anxiety and mental crisis caused by the collapse of the shogunate. Nicholas decided to spread the Gospel in earnest in the main island of Japan, and moved to Tokyo in 1872 (Naganawa, 2011) .

\subsection{The Chapels Converted from Farmer Houses}

In response to the strong demand for religious activities, in the 1870s, a number of small chapels emerged around Tohoku and Kanto regions, the eastern half of mainland Japan. At first, in 1875, a farmer house at Kannari Village (a part of Kurihara City in present), Miyagi Prefecture, was converted to a chapel. It was an ordinary rural building without any special equipment such as a gorgeous iconostasis or polychromic wall paintings, only with the exception of the small number of icons hanging by the pillar. However, it certainly was a warm and sanctified common space for the newly born Christian community. Although this chapel was destroyed by the neighbours with anti-Christian tendencies a few years later, the believers did not give up a safer shelter. The movement to build the houses of God spread to the Orthodox Christians in surrounding villages. Some chapels were converted or renovated from farmer houses or warehouses, and others were newly built, but all of them were of traditional Japanese wooden architecture (Suzuki, 1983).

After nearly 150 years, these early chapels no longer exist as active church facilities. The one exception is the former chapel of Tega Orthodox Church in Kashiwa City, Chiba Prefecture (Figure 1a), which is preserved as a cultural heritage. This building is estimated to have been built in the early nineteenth century as an annex of a rich farmer's residence. It was donated to the Orthodox Church in 1883 and sanctified to be used as a chapel. Around 1897, a structure was added to the east end to extend the space and place the altar. In 1974, Tega Church built a new chapel in the neighbourhood, and planned to demolish the old building. But as the local authorities purchased and restored it at its original location, the former chapel still exists in a pastoral scenery of Chiba (Kashiwa City, 2018).

The building is a typical farmer house in this region with a thatched roof. Its interior space is floored with tatami mats following Japanese tradition, but is uniquely characterized by the iconostasis which is a special feature of the 
Orthodox Church (Figure 1b). This amalgam of Japanese and Russian traditions is an eloquent witness of the early Orthodox faith in Japan.

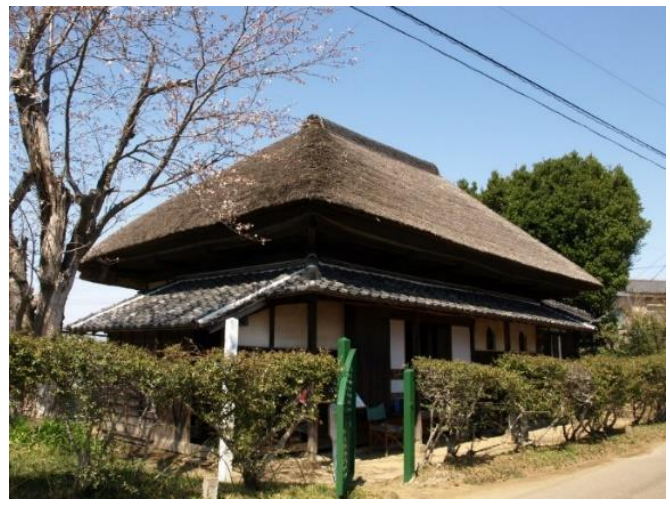

Figure 1a Former Tega Chapel

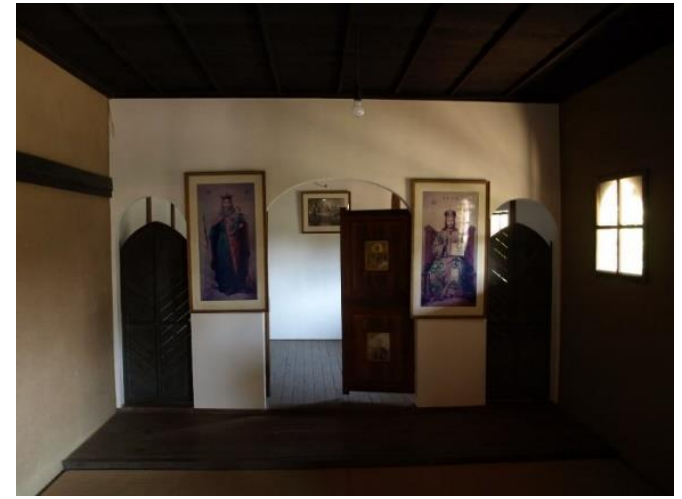

Figure 1b Tega Chapel, interior

\subsection{Eclecticism}

In the late 1870s, a group of Orthodox believers in Ishinomaki, Miyagi Prefecture, also planned to build a chapel. As a rich merchant was a member, they could economically afford to build new architecture. They hoped to make it in western style, by taking two preceding churches as models. One was the Russian Consulate's chapel in Hakodate and the other was the Nativity Church in Tokyo.

The Nativity Church was founded by Nicholas in 1874 on the hill of Surugadai in central Tokyo. It was a double storey Flemish-bond-brick architecture. Presently it is thought to have been designed by Jules Lescasse (1842-1901), a French civil engineer whose office was in Yokohama. As the upper floor has been destroyed by the earthquake in 1923 , it currently remains as a flat building on the premises of OCJ. In the late nineteenth century, Nicholas lived on the ground floor and used the upper floor as a chapel (Kawahigashi, 2008). This composition is sometimes found in private chapels of high priests at the monasteries in Russia.

Looking at the precedent in Tokyo, the believers in Ishinomaki planned a building with vertical configuration consisting of a chapel on the upper floor and an assembly space on the ground floor. A long cross-shaped plane was adopted from the precedent in Hakodate. However, the carpenters in this region did not know how to build western architecture at that time. There was no way for them to avoid the eclecticism between Japanese and Russian architectures. Their chapel was dedicated in 1879 after the name of St. John Apostle (Figure 2a) (OCJ, 2008). It was characterized by white stucco walls and a dark-grey ceramic tiled roof which were the traditional features of commercial buildings in Japan. Vertical sliding windows gave its elevation a western taste. The octagonal apse was lifted above portico supported with four columns, and the nave continued on the upper floor (Figure $2 \mathrm{~b}$ ). Two sacristies on both sides of the nave formed a transept. The assembly room downstairs was floored with tatami mats (Figure 2c). The most surprising was the narrowness of its interior space. As the height of each level was approximately $2.1 \mathrm{~m}$, and an adult could touch the ceiling by reaching his or her hand.

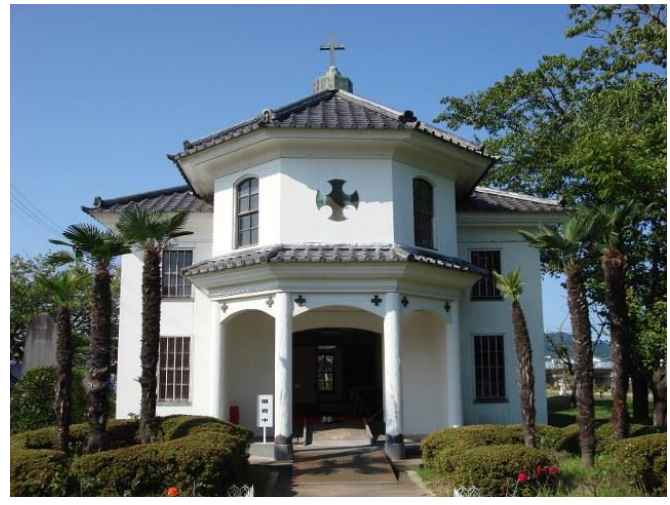

Figure 2a Former Ishinomaki Chapel

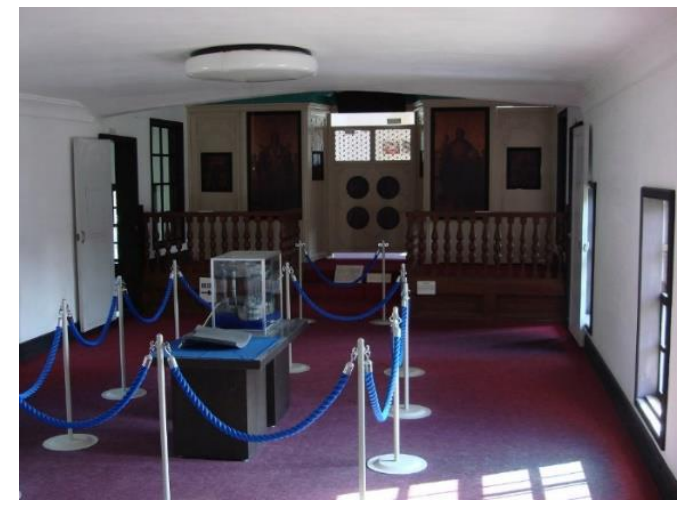

Figure 2b Ishinomaki Chapel, interior 


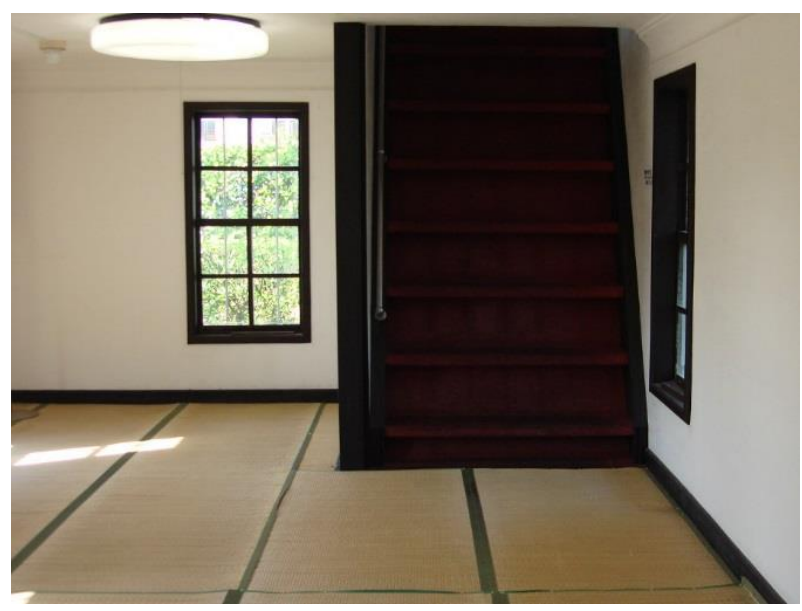

Figure 2c Ishinomaki Chapel, ground floor

St. John Apostle in Ishinomaki was damaged by the earthquake in 1978. The Church planned to demolish it and build a new building. The city authority of Ishinomaki acquired the old chapel, moved it to Nakase Park in the middle of Kitakami River (Miyagi Prefecture, 2015). In 2011, another earthquake hit this region. This time the former chapel was struck by a huge tsunami and was almost destroyed (Figure 3a). As Ishinomaki was the most damaged city by this quake, its preservation seemed impossible. However, in response to the voices not only from Christians but also from a number of citizens who aspired the repair of their city's symbol, the city administration decided to reconstruct the chapel after first dismantling the debris. This restoration work was completed in 2018 (Figure 3b).

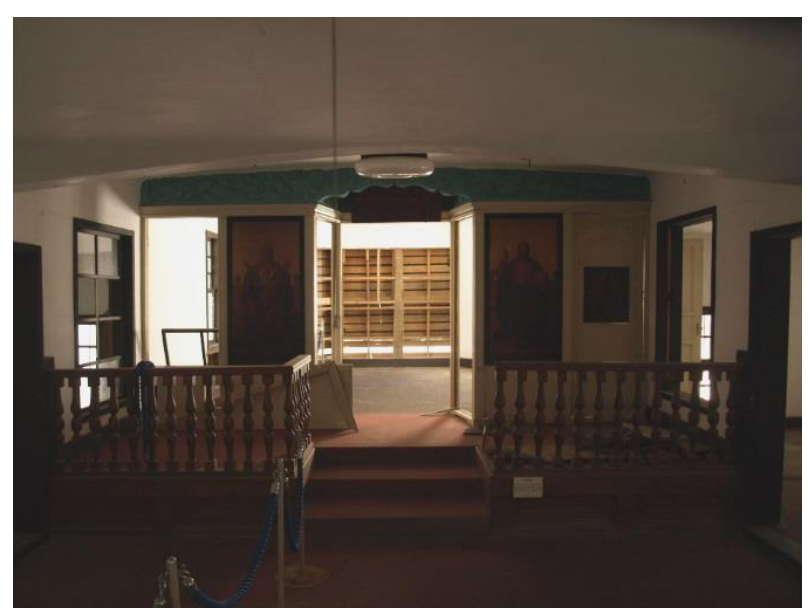

Figure 3a Ishinomaki Chapel,

interior after the quake in 2011 (2012)

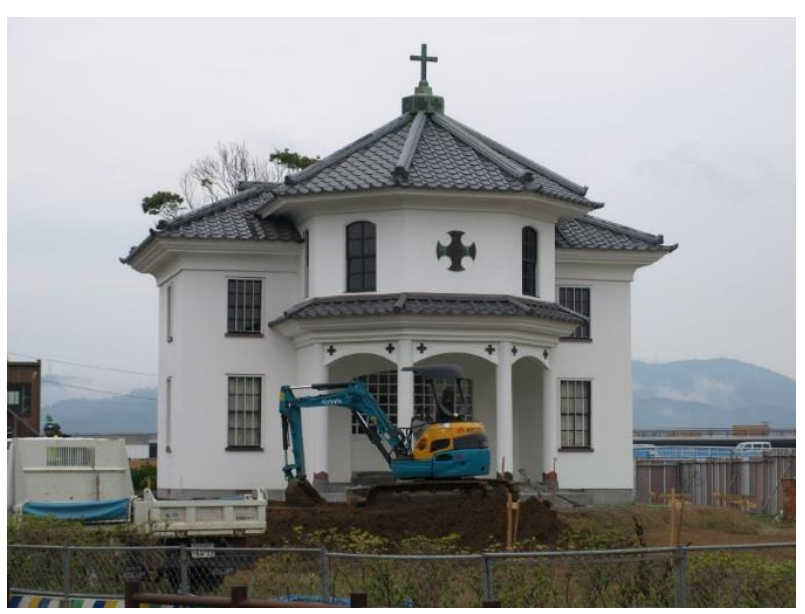

Figure 3b Ishinomaki Chapel, restored after the quake in 2011 (2018)

\subsection{The Resurrection Cathedral}

In spite of various drawbacks, St. John Apostle in Ishinomaki became a prototype of Orthodox chapels in Miyagi Prefecture. The believers in neighbouring towns, such as Wakuya and Sanuma, soon built chapels like its carbon copies. The influence remained even in a larger church built in 1902 in Ichinoseki City, Iwate Prefecture. However, the boom to build these eclectic tiny chapels in Tohoku was suddenly terminated around 1890, when a new and ideal model of church architecture was given. The construction of a huge cathedral built with bricks and steel began in Tokyo.

In 1879, Nicholas was invoked back to St. Petersburg, Russia, to be ordinated as bishop. At that time, he thought it was a good opportunity to realize his dream and called for donation to build a cathedral in Tokyo. A number of Russian celebrities including famous writer Fyodor Mikhailovich Dostoevsky (1821-1881) responded to his call and donated funds for construction. Besides financing, Nicholas looked for an architect who would design the cathedral. Recommended by the metropolitan bishop of St. Petersburg, Nicholas requested Mikhail Aref'evich Shchurupov 
(1815-1901), the professor of the Imperial Academy of Fine Arts, for drawing. Shchurupov completed his portfolio by the following spring and Nicholas brought it back to Japan (Nakamura, K. et al., 1994).

The actual construction was entrusted to Josiah Conder III (1852-1920), a British architect active in Tokyo. The site prepared for the cathedral was the east end of Surugadai Hill. Conder began to build huge walls here, with bricks in English bond. Spending seven years and costing 240 thousand yen, the construction was an unprecedented big project in Tokyo. Its excellence became clear by comparison with Rokumeikan, the national guest house which the Japanese goverment had built the year before with their pride and prestige. Although the construction was also directed by Conder as was the cathedral, it was completed after four years, costing 180 thousand yen. As the structure surrounded by scaffolding extended to the sky day by day, from the hill overlooking the Imperial Palace, xenophobic chauvinists called it the nest of Russian spies and tried to attack it. The believers had to protect the construction site.

The Resurrection Cathedral in Tokyo was dedicated on March 8, 1891 (Figure 4a, b, c, \& d). The building continued $43 \mathrm{~m}$ from east to west, and spread the wings for $33 \mathrm{~m}$. Its bell tower reached $40 \mathrm{~m}$ in height off the ground. The nave was crowned by an octagonal dome in a unique form like an inverted morning glory, directly on the brick structure without a drum. The dome of $16 \mathrm{~m}$ in diameter was framed at a height of $24 \mathrm{~m}$ above the ground, with steel ribs imported from Britain (Suzuki, 1998). It was one of the first steel structures in Japan, and at the same time, one of the largest Byzantine Revival architectures in East Asia. Aside from extreme chauvinists, most of Tokyo's citizens welcomed the new landmark and called it by the nickname 'Nikolai-do', which meant 'the temple of Nicholas'.

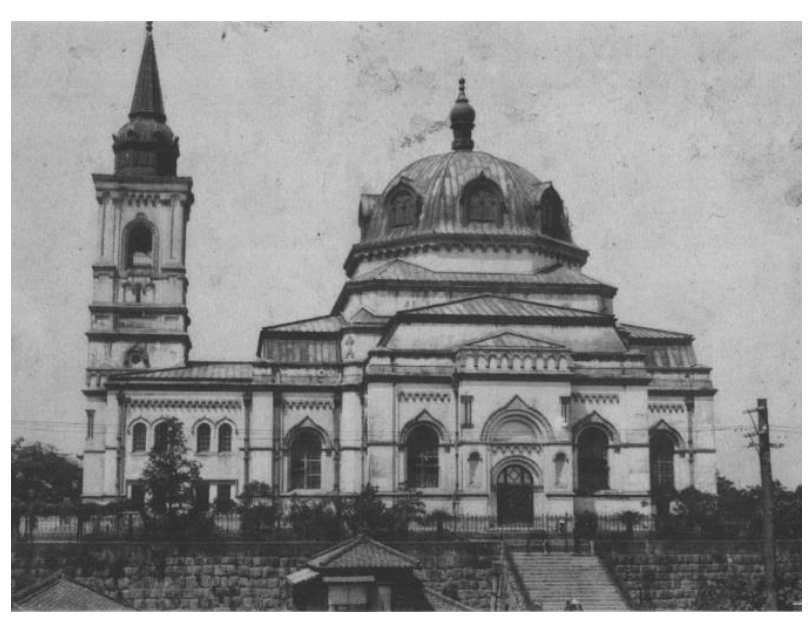

Figure 4a The Resurrection Cathedral in Tokyo,

south façade

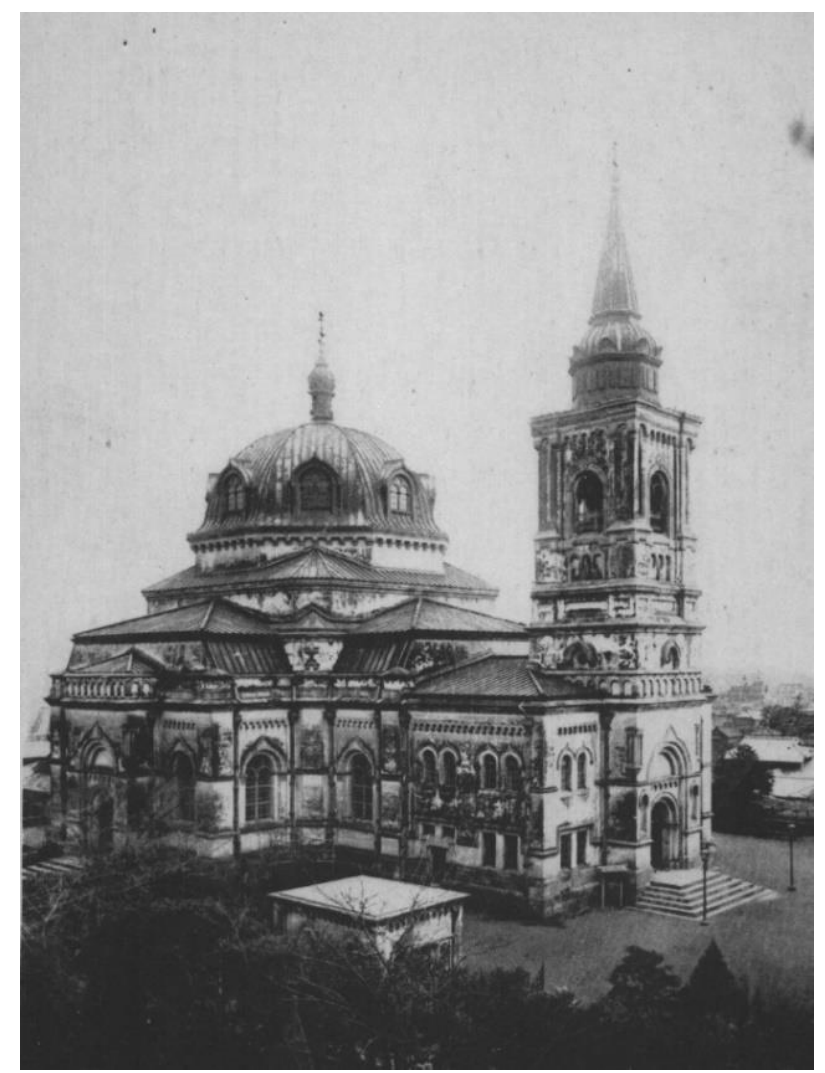

Figure 4b The Resurrection in Tokyo, view from northwest 


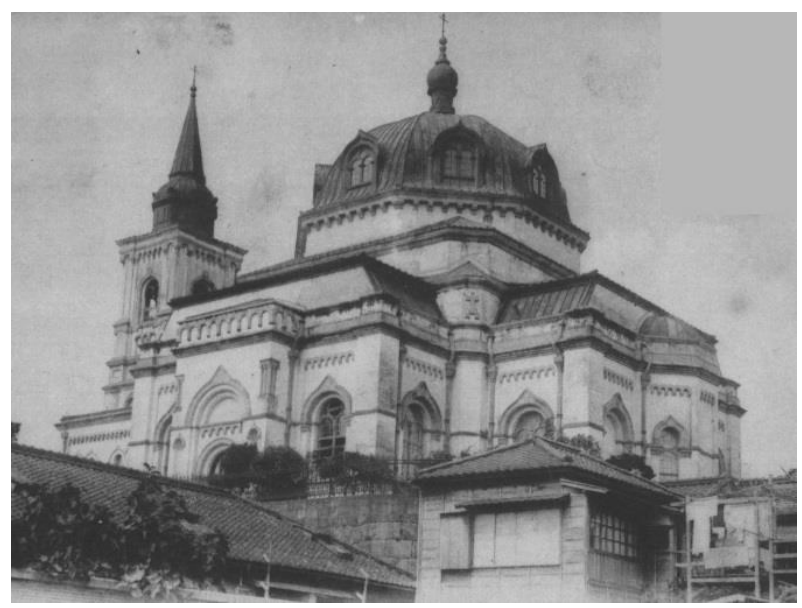

Figure 4c The Resurrection in Tokyo, view from southeast

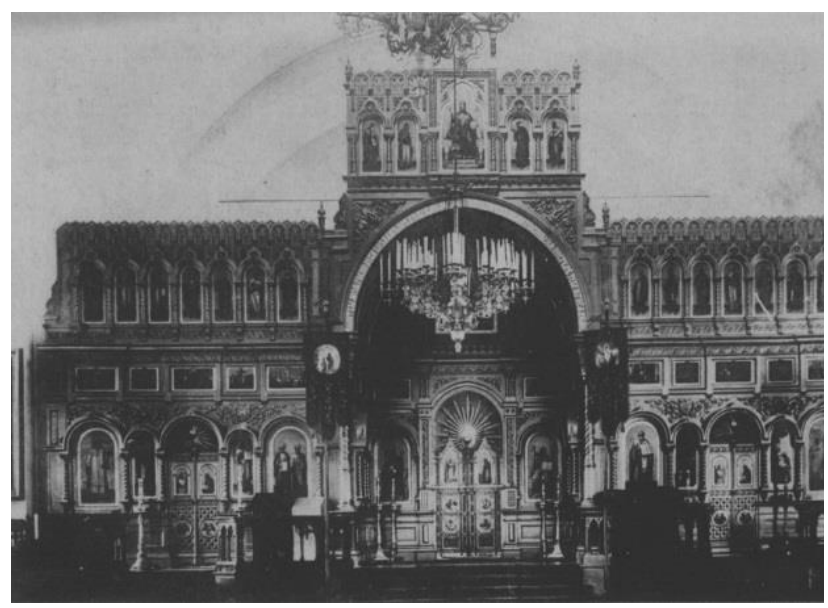

Figure 4d The Resurrection in Tokyo,

iconostasis

\subsection{Vision of Paradise}

The appearance of 'Nikolai-do' stimulated Japanese culture at that time. It was mentioned in the literary works of famous poet Akiko Yosano (1878-1942) (1909), as well as writer Soseki Natsume (1867-1916) (2011). The steel framed octagonal dome was repeated in some splendid works by Japanese architects, such as Tokyo Central Station designed by Kingo Tatsuno (1854-1919), the headquarter of Yokohama Specie Bank by Yorinaka Tsumaki (18591916) etc. and became an icon of Meiji Era, which was the reign of Emperor Mutsuhito. Nevertheless, the Resurrection Cathedral in Tokyo's greatest impact was on the architectural activities of OCJ itself. It was as early as during the construction of the Cathedral in Tokyo that the Pentecost Orthodox Church was dedicated in 1886, in Odawara, Kanagawa Prefecture. Although it was a wooden architecture, its nave was broad and nearly square, and was covered by a pyramidal roof supported by ridge beams (Momose, Hiroishi, Yamaguchi \& Kamiya, 2002). The Annunciation Church in Sendai followed these tendencies in 1892, with a wooden structure and a large nave in an octagonal plane (Suzuki, 1983). The attempts to reproduce the Resurrection Cathedral in a smaller scale with wood had begun.

The most astonishing example of the parish church architecture in this period still remains in Odate City, Akita Prefecture. The Annunciation Chapel at Magata for the Orthodox Church in Hokuroku (Figure 5a, \& b), dedicated in 1892, is a smaller building, even compared with the St. John Apostle in Ishinomaki, but its interior space is filled with rich architectural vocabularies of Russia and the West (Figure 5c). The centre of the nave is covered by a wooden hemispherical ceiling under an octagonal pyramidal roof (Figure 5d). Its plane is cross-shaped though both transepts have only less than $1 \mathrm{~m}$ of width. The ceilings over them do not play any structural role, but are beautifully formed as arches. The iconostasis has a simple composition with one layer and five rows, but it is authentically Russian styled, and decorated by splendid icons including the works by Rin Yamashita (1857-1939), Japan's first female western painter. All these elements including the building itself are made very carefully with local cedar. It is a reproduction of the Resurrection Cathedral in Tokyo, condensed on a miniature scale, and at the same time, a vision of paradise given to the people in the snowiest region in Japan. 


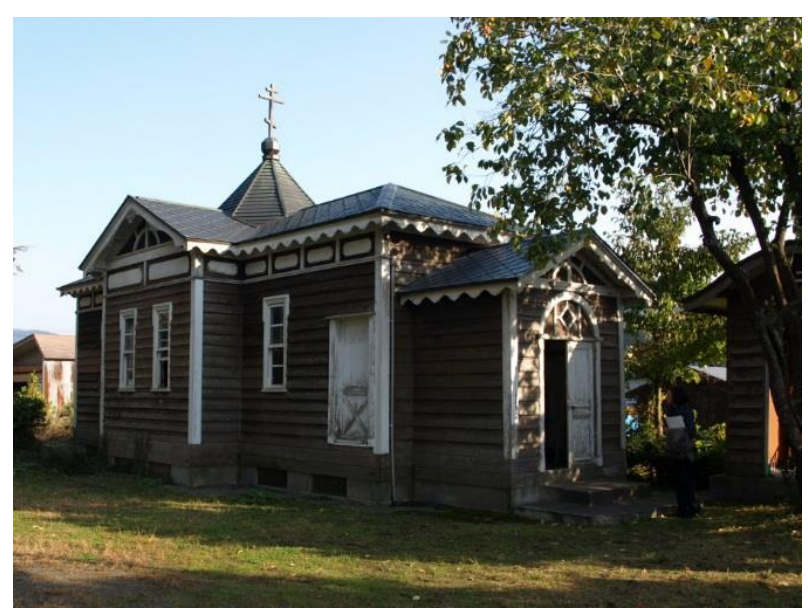

Figure 5a The Annunciation at Magata,

view from northwest

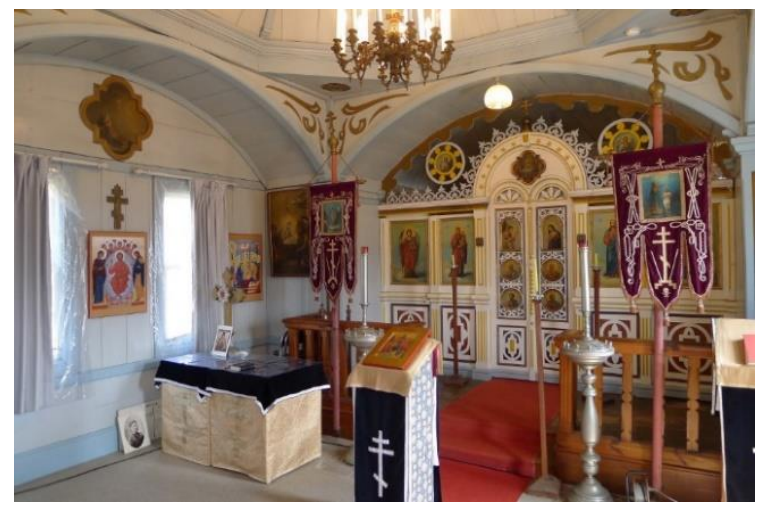

Figure 5c The Annunciation at Magata,

interior

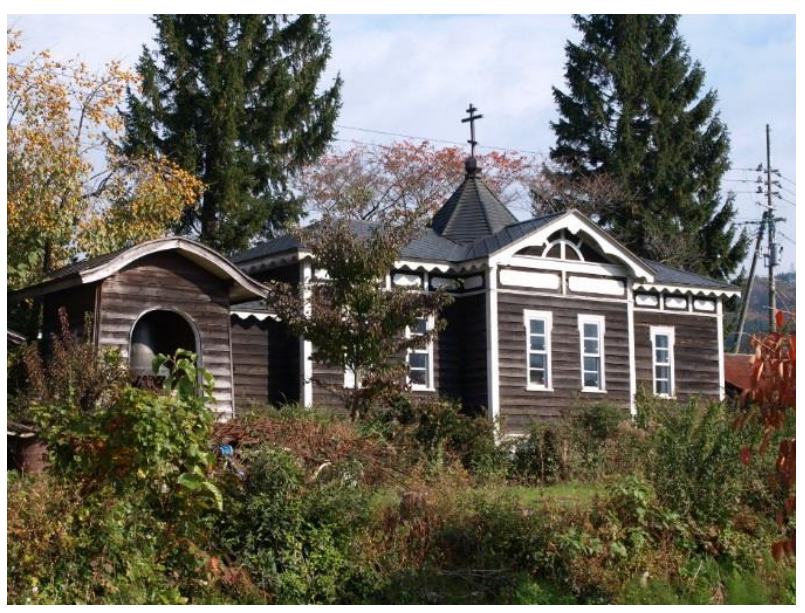

Figure 5b The Annunciation at Magata, view from southwest

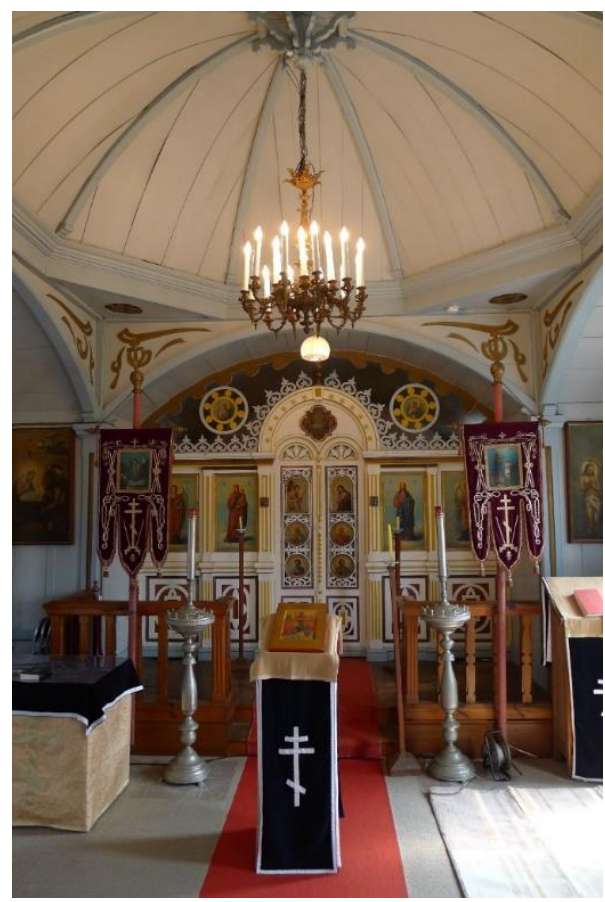

Figure 5d The Annunciation at Magata,

hemispherical ceiling and iconostasis

The Resurrection Cathedral in Tokyo gave great influence to many Orthodox Churches, not only those mentioned above. The structure itself, however, was seriously damaged by the earthquake in 1923 (Figure 6a). Its $40 \mathrm{~m}$ high wooden bell tower collapsed. Its steel framed dome melted down due to the violent fire in the neighbourhood. The repair work was left to Japanese architect Shinichiro Okada (1883-1932). Okada newly designed and reconstructed the tower and dome, both made from reinforced concrete, and added structures to withstand their weights (Figure 6b). As a result, the cathedral became safer, but its form changed from the original Byzantine Revivalism. In order to know its original features and design intentions, it is necessary to see other works by the same architect. 


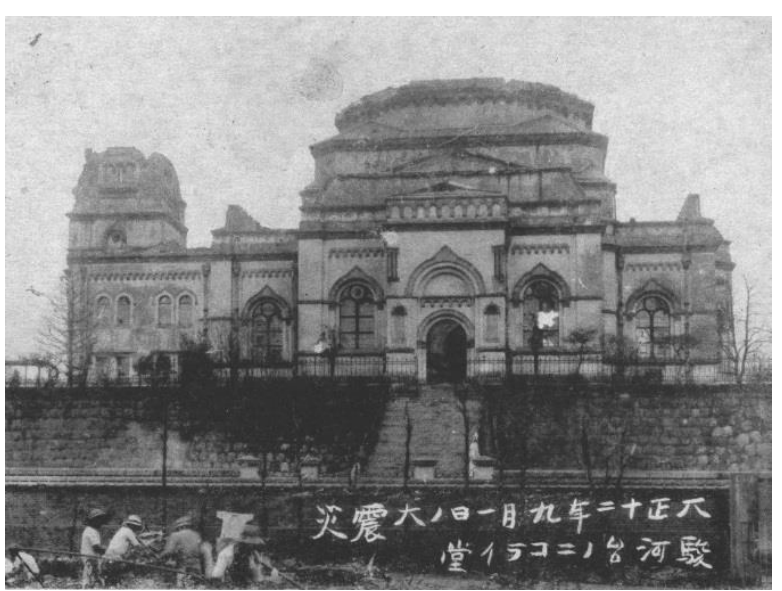

Figure 6a The Resurrection in Tokyo

after the quake in 1923

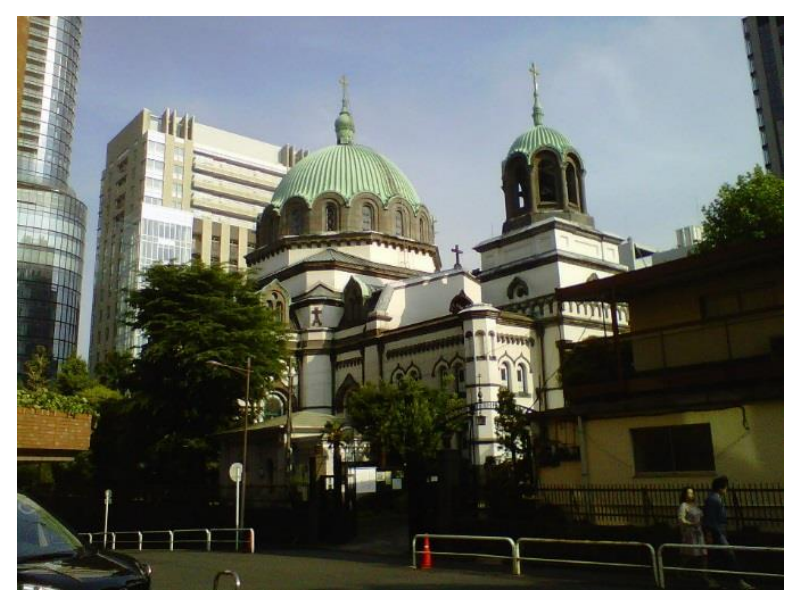

Figure 6b The Resurrection in Tokyo,

restored current state

\section{Architect Mikhail A. Shchurupov}

Mikhail Aref'evich Shchurupov was born in 1815 in Arensburg (Kuressaare, Saaremaa Island, Estonia, in present) and grew up in St. Petersburg. He was educated in the Russian Imperial Academy of Fine Arts, then in Rome for six years. At the end of the study period, he caused trouble with the home government, and spent nine years of de facto exile in Italy. He was back in Russia in 1855, and later built a number of churches in the southern and eastern suburbs of St. Petersburg (PP, 1883). However, only three of them remains in present, functioning as Christian facilities.

\subsection{The St. Nicholas the Miracle Worker at Kobona}

After returning to Russia, Shchurupov's first work was a church at Kobona, a small village on the shore of Ladoga, the largest lake in Europe, approximately $100 \mathrm{~km}$ from St. Petersburg. The St. Nicholas the Miracle Worker Church at the village had been burnt in 1815 , and the villagers had prayed at a temporary church when Shchurupov came there.

The architect was ordered to reconstruct the church in 1860 (Yakovlev, 2001). He formed the new church by connecting two impressive mass pieces by a simple gable roof (Figure 7a). One was the narthex with a classical propylaeum, which was crowned by a high-rising bell tower, and the other was the main part of the nave under a pyramidal roof, which was traditional in Russia.

Its propylaeum has a pediment supported by four Doric columns (Figure 7b). The combination of a pedimental façade and a high pointed tower obviously imitates St. Martin-in-the-Fields in London designed by James Gibbs (16821754), on a much smaller scale. On the other hand, the pyramidal roof with five onion domes on summit and ridges is an architectural tradition of the Russian Orthodox Church since the Middle Ages. However, instead of the traditional structure, in which pillars support the middle of ridge beams, at Kobona, a stable rectangle is formed on the top of pillars and side walls to support the entire structure of roof. Despite having both the British neoclassical façade and the Russian traditional central part, its harmonious and well-balanced appearance displays Shchurupov's excellent sense of geometrical proportion.

Shchurupov completed the new building for the St. Nicholas the Miracle Worker Church at Kobona in 1861. The depth of its nave was approximately $16 \mathrm{~m}$, and the width was $13.5 \mathrm{~m}$, both by the inner method. It was by no mean large scaled, but a neat and beautiful church, and became a pride of villagers for a long time. 


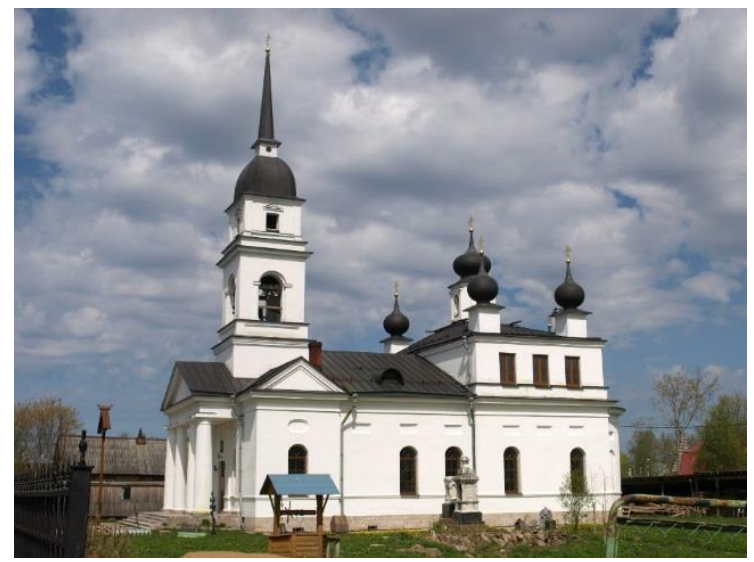

Figure 7a The St. Nicholas at Kobona, view from southwest

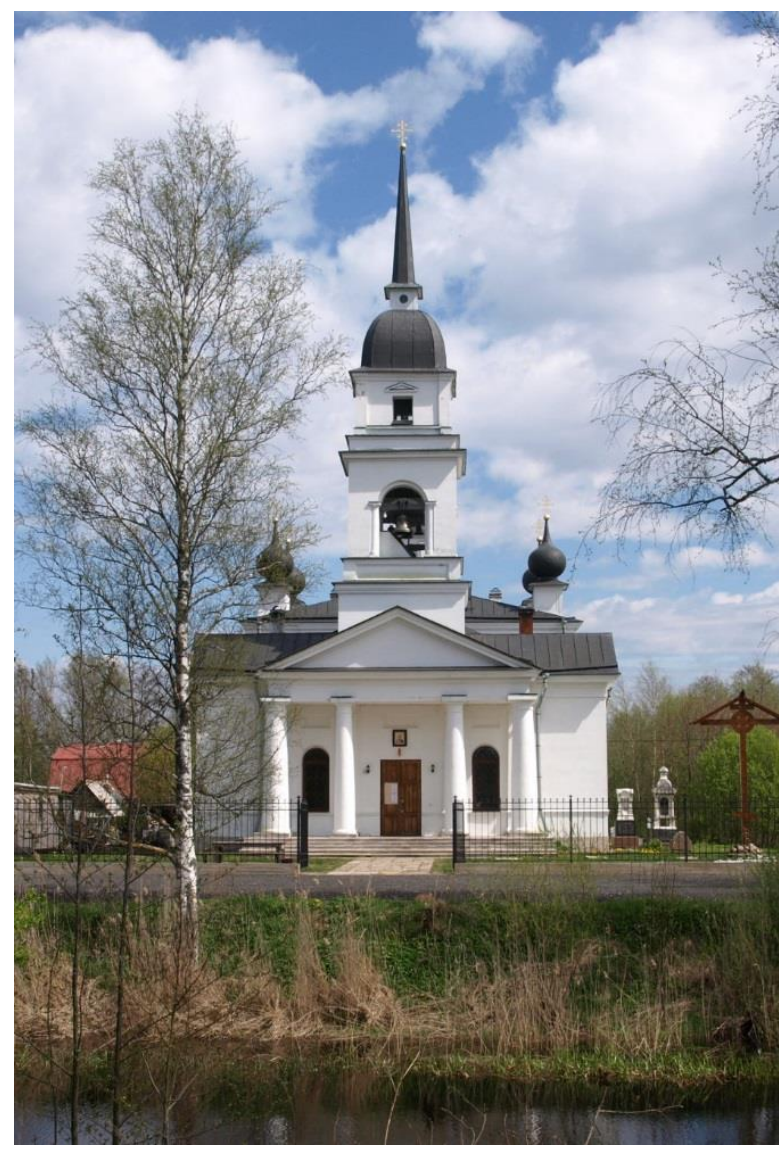

Figure $7 \mathrm{~b}$ The St. Nicholas at Kobona, west façade

After the revolution in 1917, the church was closed and forfeited by the government, and during the World War II, was used as a shelter of refugees from Leningrad siege. When the Soviet Union collapsed, the church has been neglected for many years and devastated. From 2000, it was placed under the administration of the Holy Trinity Monastery in Zelenets, authentically restored, and regained its original state.

\subsection{The St. Alexander Nevsky at Ust'-Izhora}

From 1866, Shchurupov started designing the Sts. Boris and Gleb Cathedral at Kalashnikov Riverbank, St. Petersburg, and completed it by 1882 . This cathedral is regarded as his masterpiece but no longer exists.

In 1870, Shchurupov received the request to design the reconstruction of the St. Alexander Nevsky Cathedral at Ust'Izhora, in the south suburbs of St. Petersburg. Ust'-Izhora settlement is located on the node where Izhora River flows into Neva, where it is believed that the force of Novgorod defeated Sweden in 1240. St. Alexander Nevsky, or Aleksandr Yaloslavich, is a prince who led the force of Novgorod in the battle.

Although the population of the area was not large, additional space was needed for the cathedral to accommodate for the pilgrims, because it was at the place of holy saint. However, the ground was weak at the confluence point of the two rivers, and construction funds were not abundant.

Shchurupov responded to these challenges with the lightweight and inexpensive structure which is a wooden dome. The architect left the existing bell tower shaped like a lighthouse, which was originally built in 1830s, and rebuilt the rest of the building. He expanded the nave with stone walls, and gave each end of transept a pedimented façade. He thought to cover this large space with a Italian-styled classical dome. The special point was that the dome would be made from wood. 
Although Russia had a long tradition of wooden structure, and some of large-scaled neoclassical buildings built in the eighteenth and nineteenth centuries were featured by wood-framed brick domes, the attempt to build an entire large-scaled dome only with wood was unprecedented. The regional authorities spent a year verifying its safety, and approved of it at last, under the condition that the architect will notify the authorities as soon as any problem should occur. The dome was constructed on an octagonal drum which is also wooden. Eight dormer windows, which were not shown in the architect's early drawing in 1870, were added. The cathedral was dedicated in 1875 (Figure 8) (Yakovlev, 2001).

The Alexander Nevsky at Ust'-Izhora was closed after the revolution, and its dome and bell tower were lost due to the war and long-term neglect. However, it was authentically restored after the end of the Soviet Union. The light falling from the dormer windows to the nave is dramatic.

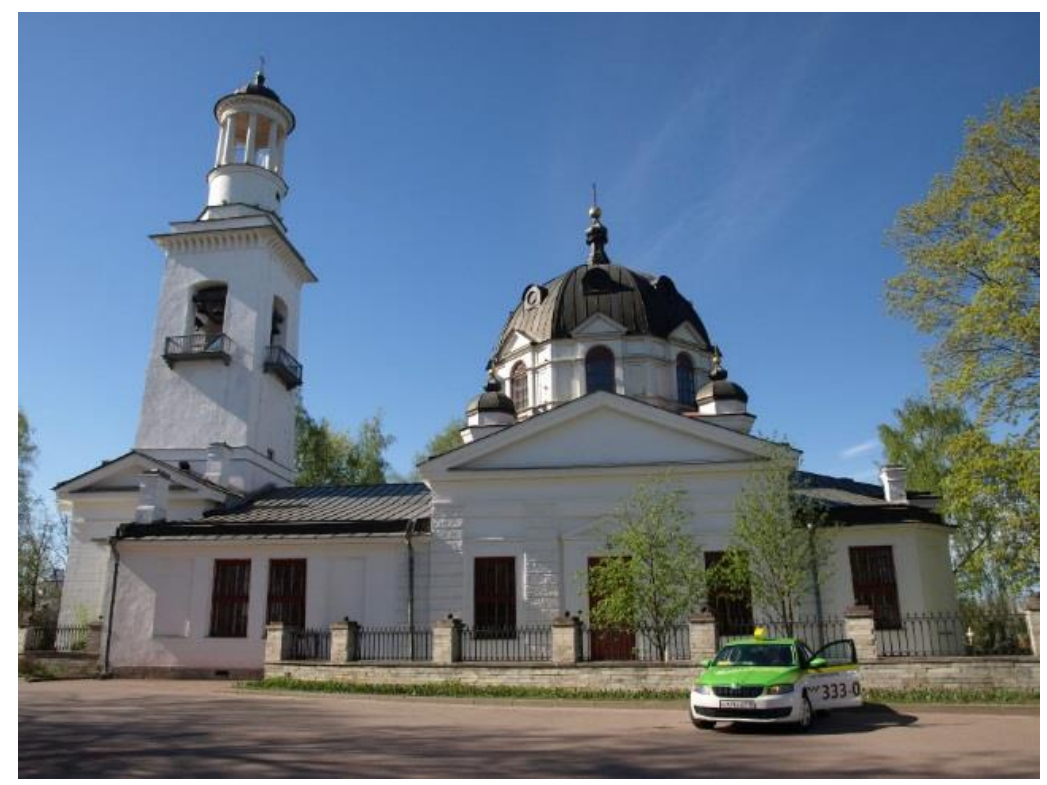

Figure 8 The St. Alexander Nevsky at Ust'-Izhora

\subsection{The Nativity of the Theotokos in Novaya Ladoga}

Suchurupov conducted the repair procedure of the Church of the Nativity of the Theotokos in Novaya Ladoga, from 1876 to the next year. Novaya Ladoga is a small city located on the west side of the river mouth where the Volkhov flows into the Lake Ladoga. The Nativity of the Theotokos was originally dedicated in 1702, when the city was founded by Peter the Great. In Shchurupov's era, despite being less than two centuries since its construction, the stone basement was in a dangerous state because of the subsidence of the ground.

Shchurupov proposed to reconstruct the floor using joists, beams and girders, move the apse and altar to extend the nave to a depth of $20 \mathrm{~m}$, rebuild the portico, reinforce and redesign the side walls, and newly construct a steel and wood dome with wooden pendentives. The steel and wood dome meant a double shell consisting of a steel framed roof, and a wooden hemispherical ceiling. Since the steel framed dome did not require the load dispersion by pendentives, the wooden pendentives were ornamental. The use of wood was aimed at shortening the construction period and reducing the cost. Shchurupov also omitted a drum under the dome for the same reason. The proposals were approved on June 26, 1876, by the Ministry of Interior, and the construction started within the same year. The church was dedicated on October 9, 1877 (Figure 9a) (Yakovlev, 2001).

During World War II, the Nativity of the Theotokos in Novaya Ladoga was burnt by the German air raid, and its unique hybrid structured dome was destroyed. Although the church was restored after the war, the shape of the dome changed from its original, as the restoration was conducted with the limited resources which the church was allowed to use under the socialist regime (Figure 9b). Only the photographs taken before the revolution convey the unique shape of its dome, which was like an inverted flower. 


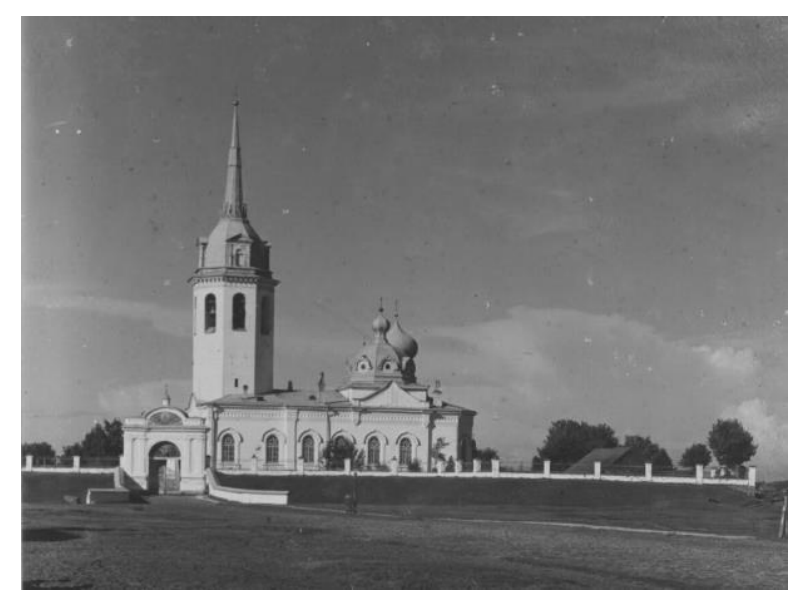

Figure 9a The Nativity in Novaya Ladoga,

original south façade

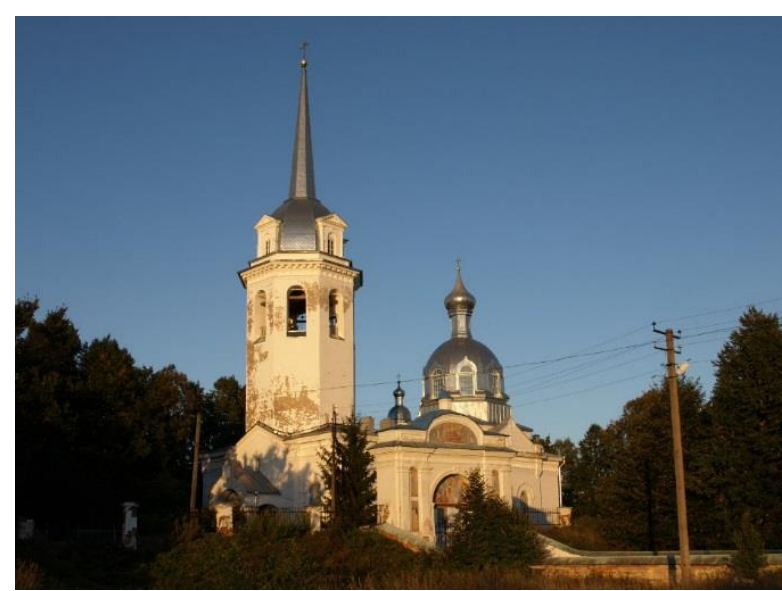

Figure 9b The Nativity in Novaya Ladoga, restored current state

\section{Discussion}

The central part of the Annunciation Chapel at Magata, Odate, Akita Prefecture, is a testament to the high level of Eastern Orthodox architectural activities in its early period of missionary in Japan.

The interior space of Christian church buildings can be formally or structurally divided into several smaller parts. However, from the functional view point, it is made up of three parts, the sanctuary, the space of prayer, and the space of entrance or initiation. In many cases they coincide with apse, nave and narthex. It is not a spetial feature of Eastern Orthodox but a common tradition of many denominations of Christianity. However, at the Orthodox churches, where a sanctuary is divided from a nave by an iconostasis, this spatial and functional division is emphasized and visualized. The sanctuary is clearly forbidden.

All these spaces are sanctified, but the spiritual stage is higher as the space becomes physically closer to the sanctuary. The sanctuary is the place for altar as it physically is, but at the same time, during the liturgy, it symbolically plays various roles, as Jerusalem, its temple, the seat of the resurrected Jesus, and the heaven. The nave and its hemispherical ceiling symbolise the entire universe created by the Lord, but in response to the multiple roles of the sanctuary, this space also changes the meaning. Then, through this kind of spiritual theatre, the believers experience the visit of heaven in pseudo manner. This simulation is important in order to pass on the faith across generations. An Orthodox church is not only a ritual facility but also an educational existance. Therefore, the fact that the early believers in Japan created the brilliant nave of the Annunciation at Magata, to project the vision of paradise there, means that they had reached the essence of Orthodox church architecture.

The Resurrection Cathedral in Tokyo was a culmination of Shchurupov's architectural achievement. Comparison of shapes that remain in existing works and pictures show, that the architect evidently brought prominent elements of past work into this piece, and expanded them to a large scale. The high spire of British neoclassical style was from Kobona, and the steel framed octagonal dome without drum was from Novaya Ladoga.

Shchurupov's idea of merging western and Russian styles, shown at Kobona, although not refined at the time, was finished elegantly, with an excellent proportional sense. Another notable point at Kobona was the structural rationalism he showed in making the pyramidal roof. This rationalism bloomed at Ust'-Izhora, and led the architect to the technical adventure of the wooden dome. Through this adventure, he also found a dramatic effect of the dormer window. Then at last, he reached to the steel framed dome, without drum, in Novaya Ladoga.

In the 1870's, steel structure had already been introduced to Russia. Viktor Aleksandrovich Shreter (1839-1901), who studied in Germany, and young architects who supported him, formed the Petersburg Society of Architects in 1862 and began to promote the steel structure (Brumfield, 1991). However, their young enthusiasm was driven by the desire to introduce German advanced technology and to enable large-scaled structures. 
Shchurupov started from a different point, tried a lightweight and inexpensive structure for the economically challenged parish suffering from difficult geological conditions, and reached the steel structure. Coincidentally, these aspects of his architecture were suitable for OCJ, where the believers chose their faith under difficult circumstances and would spend a long time as a religious minority since then, in severe natural conditions, exposed to many earthquakes, typhoons, heavy rain and snowfall.

\section{Conclusion}

The facility of Eastern Orthodox in Japan began with conversion of existing private houses to chapels, with the necessity to secure places of worship. The eclectic chapel buildings in Tohoku region followed. The construction of the Resurrection Cathedral from 1884 became a turning point.

The Resurrection Cathedral in Tokyo gave strong impact to the building activities of OCJ. Members of the church reached the concept to represent a vision of paradise under the hemispherical ceiling which embodies the universe made by the Lord.

Mikhail Shchurupov started from his own perspective, stood on rationalism, repeated the quest, and produced his own lightweight structure and distinctive form. His concept reflected in the Resurrection Cathedral enabled Japanese believers to maintain their worship facilities for a long time. Though he is almost forgotten in recent times, Mikhail Shchurupov is one of the visionary architects of the nineteenth century.

\section{Authors' contributions}

This paper has one and a single author. The author read and approved the final manuscript.

\section{Acknowledgements}

Figures $4 \mathrm{a}, \mathrm{b}, \mathrm{c}$ and $\mathrm{d}$ are quoted from old postcards published in the early twenteenth century, and 6a is also from a postcard published in 1920s, in Japan. Figure 9a was taken in 1909 by Sergei Mikhailovich Prokudin-Gorsky (18631944). The copyrights for all these photographs expired. Figures $4 \mathrm{c}$ and $4 \mathrm{~d}$ are taken by Seizo Uchida of Kanagawa University and presented to the author. All other photographs are taken by the author. The language quality control of this manuscript was conducted by Atsuko Nakao.

\section{References}

Brumfield, W.C. (1991). The Origins of Modernism in Russian Architecture. Berkeley: University of California Press.

Christian Yearbook Editing Committee (2017). Christian Yearbook 2017. Tokyo: The Kirisuto Shinbun.

Ishikawa, Y. (2018). On the Architectural History of the Annunciation Church for Kyoto Khristos Orthodox Church. Bulletin of Kyoto City Cultural Heritage Protection Division. 1. 16-25. http://kyoto-bunkaisan.com/report/pdf/kiyou/01/02 ishikawa.pdf (Accessed March 12, 2020)

Izumida, H. (2013). Russian Orthodox Church Architecture in Japan: Application of Synod's Model Church Plan in Japan [Presentation]. Special Lecture for the 100 Years Anniversary of Foundation of Toyohashi Orthodox Church. https://www.researchgate.net/publication/324115929_Russian_Orthodox Church Architecture in Japan Application_of SYNOD's Model _Church_Plan_in_Japanzongwujuchengrenjiaohuitumianantoribennozhengjiaohuishengtangjianzhu (Accessed February 29, 2020). DOI: 10.13140/RG.2.2.14496.89609.

Izumida, H. (2018). Saint Nikolai and SYNOD-Approved Model Church Plan in Japan [Preprint]. ResearchGate. https://www.researchgate.net/publication/327857972 Saint Nicholas of Japan and SYNODApproved Model Plans for Orthodox Churchnikoraitoroshiazongwuyuanchengrennodefangzhengjiaohuishengtangshejitupu (Accessed February 29, 2020). DOI: 10.13140/RG.2.2.27450.64963

Izumida, H., Ito, H., \& Nishizawa, Y. (2010). A Study on Toyohashi Khristos Orthodox Church : Analysis of Construction Process and Planning Through Lately Found and Published Records. J. Archit. Plann. AIJ. 75 (654). 1997-2005. https://www.jstage.jst.go.jp/article/aija/75/654/75_654_1997/_pdf/-char/ja (Accessed February 29, 2020).

Kashiwa City (2016). Former Tega Chapel and Its Icons. http://www.city.kashiwa.lg.jp/soshiki/280400/p001477.html (Accessed March 12, 2020).

Kawahigashi, Y. \& Fujiki, R. (2008). The Research Report of the Buildings Attached to the Resurrection Cathedral in Tokyo (Nikolai-do). Chiba: Chiba Institute of Technology, Kawahigashi Laboratory.

Kishkinova, E. M. (2007). «Byzantine Revival » in Russian Architecture. St. Petersburg (Russia): Iskusstvo - SPB.

Miyagi Prefecture (2015). Reconstruction: Cultural Assets of Miyagi Prefecture. http://www.thm.pref.miyagi.jp/fukkou/harisutosu.html (Accessed November 25, 2018).

Momose, T. H., Hiroishi, V. H., Yamaguchi, M. Y., \& Kamiya, M. Y. as History Compilation Committee of Odawara Orthodox Church (2002). 120 Years History of Odawara Orthodox Church. Odawara: Odawara Orthodox Church. 


\section{Ikeda / Proceedings of Science and Technology}

Naganawa, M. (2011). A Brief History of Nikolai-do, Tracing the 150 Years of Acceptance of Russian Orthodox : Eurasia Booklet 169. Tokyo: Toyo Shoten.

Nakamura, K., Nakamura, Y., Yasui, R., \& Naganawa, M. (1994). The Diaries of St. Nikolai of Japan. Sapporo: Hokkaido University Press.

Natsume, S. (2011). And Then (N. M. Field. Trans.). Tokyo: Tuttle Publishing (Original work published in 1909).

P. P. (the interviewer only known by initials) (1884). Mikhail Arefievich Shchurupov, Professor of Architecture. Russkaya Starina, 42 , $408-424$.

Savel'ev, Y. R. (2005). «Byzantine Style» in Russian Architecture : The Second Half of the XIXth - the Beginning of the XXth Century. St. Petersburg (Russia): Liki Rossii - Proekt 2005.

Suzuki, K. (1983). The Architecture of the Orthodox Church in Japan. Unpublished master thesis presented to Nagoya University.

Suzuki, S., Takamura, K., \& The Japanese Association for Conservation of Architectural Monuments (1998). The Preservation and Repair Working Report on the Resurrection Cathedral in Tokyo (Nikolai-do) of the Orthodox Church in Japan. Tokyo: The Orthodox Church in Japan.

The Orthodox Church in Japan (OCJ) (2006). Orthodox Churches All Over Japan. http://www.orthodoxjapan.jp/area-higashi.html (Accessed March 12, 2020).

Yakovlev, N. A. (2001). Mikhail Shchurupov. St. Petersburg (Russia): Beloe i Chornoe.

Yosano, A. (1909). Sahohime. Tokyo: Hiyoshi-maru Shobo, stored in the digital collection of the National Diet Library of Japan. http://dl.ndl.go.jp/info:ndljp/pid/873368 (Accessed on March 21, 2019). DOI 10.11501/873368. 